\title{
LII. Some remarks on the granite found near Penryn, and on the mode of working it
}

\author{
John S. Enys Esq.
}

To cite this article: John S. Enys Esq. (1833) LII. Some remarks on the granite found near Penryn, and on the mode of working it , Philosophical Magazine Series 3, 2:11, 321-325, DOI: $10.1080 / 14786443308648050$

To link to this article: http://dx.doi.org/10.1080/14786443308648050

册 Published online: 01 Jun 2009.

Submit your article to this journal $₫$

Џ Article views: 3

Q View related articles $\sqsubset$ 


\title{
LONDON AND EDINBURGH
}

\section{PHILOSOPHICAL MAGAZINE}

\author{
A ND \\ JOURNAL OF SCIENCE.
}

[THIRD SERIES.]

$M A Y 1833$.

LII. Some Remarks on the Granite found near Penryn, and on the Mode of roorking it. By JoHn S. Enys, Esq.*.

THE chief intention of this paper is to give publicity to the opinions of the persons employed in the supply of granite shipped at Penryn, and to explain the mode of procuring the rectangular blocks of granite which are used in the construction of large bridges, docks, \&c. \&c. This hard and compact granite appears to run in parallel ranges through a coarser and softer variety, forming together a granitic district northwest of Penryn, of nearly a circular form, 7 or 8 miles in diameter. One of these ranges is situated on the northern side of the district: another near Penryn on the southern limits. The latter runs N.E. and S.W., and is about 5 miles long and from 1 to $1 \frac{1}{2}$ wide; it is marked throughout by large loose rocks on the surface, from whence for many years the quantity exported was obtained. An immense supply from this source is still obtainable; but about five or six years since a second bed was found under some of the larger rocks, and this in several places has been worked in quarries, locally termed " bals": these workings are so numerous as to afford strong proof of a contihuous range of hard granite. The stone is found more free from stains in depth than at the surface, though the supply is too abundant to require the workings to be carried in any instance to a depth exceeding 14 or 15 feet.

To prevent any misunderstanding, it may be advisable to 'explain in what sense several words will be used. Rock will mean either a solid mass contained between the natural joints

- Communicated by the Author.

Third Series. Vol. 2. No. 11. May 1833. 
of the granite, varying in size from 10 to 500 tons, or loose rocks of equal size; many of these last, however, are probably in their original position, if any judgement can be formed from the coincidence both of the remains of the natural joints and of the "cleaving line," with the quarry masses : such seems the case with the Main Rock or Tolmen, a remarkable and well-known rock, situated near the centre of the hard granite line; it is supported on several large rocks by two points, and measures about 500 tons.

Granite is always measured, and 14 cubic feet are allowed to a ton; though $13 \frac{1}{2}$ of fine grit will generally amount to that weight.

Cleaving is used to express splitting up a rock into blocks for sale.

The joints both of the hard and softer granite are very similar, but are more frequent and numerous in the latter variety. They have a strong tendency to meet at right angles, so as to form masses or rocks of a rectangular shape; these are often 50 feet long, and from 10 to 25 feet deep, and seem exactly similar to those at the Land's End and Cape Cornwall, and to the Logan Rock.

A small quantity of a softer stone is occasionally found between some of the joints, which is not observed to be present in exposed headlands. The Arris is likewise square, but on rocks long exposed to the influence of the weather it seems to have been rounded. The rectangular form, however, is as strongly marked as in the quarry, the joints of which are generally visible, though the granite seems in most instances to be in actual contact. Occasionally a rock has been split within two inches of a joint, which has only been found 'by the breaking of the blocks in working. One of these joints is nearly horizontal, and is called the Bed-way or Floor, and two are nearly perpendicular, one of which is found generally to run in a direction N.N.W. and S.S.E. with a variation of 15 or 20 degrees either way; the third being across. In some quarries this arrangement is extremely regular, though in others many of the joints are "unconformable." Fortunately, blocks for buildings are mostly required of rectangular forms, so that rocks are often split up to great advantage.

To form a cubic block, it is evident three ways of cleaving are required: these are termed by the cleavers or stone-cutters,

1st, Capping or Quartering:

This is a line parallel to the horizontal bed-way or floor. Capping is the term used for splitting off the top of a rock in its natural position, or of a block split off which lies as when found in the quarry. Quartering is the term when the block 
is placed on edge, as it usually is when the vertical cleaving has been first effected. The identity of these terms, in regard to the direction of the cleaving, must be attended to in speaking to stone-cutters; they refer only to the different positions of the blocks of granite. The granite splits most easily on this line, and its existence is strongly asserted to be found in some varieties in which the "cleaving line" is not so strongly marked: it is likewise notorious that it is found in elvan or porphyry; so that a workman by attending to this point, constantly gains more wages than others in breaking stones for roads at tutwork*. It is readily known in the quarry; but some skill and practice is required to find it in separated stones :

2nd, Cleaving :

The "cleaving line" is vertical, and is said by the stonecutters to be in the general direction of the crystals of felspar: it is instantly pointed out by them, but is more readily seen in coarse than in fine grit. Near Penryn it runs N.N.W. and S.S.E., varying 15 or 20 degrees either way: it consequently generally coincides with one of the vertical natural joints, though in many instances it does not correspond, but crosses them, often at an angle of 30 or 40 degrees. In these cases it appears the cleaving line, or general direction of the felspar crystal, keeps it in a N.N.W. and S.S.E. direction, and the joints are "unconformable." Part of the Cornish parapet of London Bridge was supplied from a rock which was split up parallel to the joints, and diagonally across the cleaving line, to prevent waste of stone. The appearance is exactly similar to a common observer, though a practised cleaver would probably point out every stone from that rock, certainly if allowed to break the stone:

3rd, The tough way, or across the grain:

This is asserted by the stone-cutters to be a tranverse section of the felspar crystals, and at right angles with the cleaving line.

The power required to effect a fracture on these lines is very different, and has been estimated in the following proportions :-

1st. Capping or quartering ........................ $=2$

2nd. Cleaving ........................................

3rd. The tough way ............................... $=5$.

In one trial of the tough way and capping way the power used was estimated as follows:-

* Tutwork is the term used in Cornwall to denote work contracted for with the workmen by measure.-EDrT. 
$\left.\begin{array}{c}\text { Inches. Inches. Sq. In. Power. } \\ \text { The capping way } \\ \text { measured ....... }\end{array}\right\} 24$ by $26=624 \ldots \ldots 5\left\{\begin{array}{l}2 \text { Wedges, } \\ 1 \text { Ripper. }\end{array}\right.$

The tough ditto 24 by $15=360 \ldots \ldots$....3 Wedges.

This, as far as one trial can do so, more than proves the stone-cutter's assertion;-the cleaver likewise added that the tough way was struck rather harder than the other. The cleaving can be effected on any diagonal line, but the fracture is untrue; it is almost invariably true both on the capping and cleaving lines, though less on the tough way.

In cleaving granite two varieties of gear are in use, Wedges and Cues, - the latter so called from the ox-shoes, which were first used for the purpose; and Rippers and Feathers. The ripper is sometimes called a Tearer; it is only a tapered bar of iron, in fact a circular wedge; it is used in deep holes formed by a borer or jumper; the last is well known in quarries, the former is beat by a man with a sledge-hammer, and turned in the hole by a boy who holds it. The wedge is placed in a groove cut about three inches deep. The cues and feathers are thin slips of iron acting in a similar manner, and are respectively placed against the sides of the groove or hole when the wedge or ripper is placed between them, and struck down with a sledge-hammer, generally of 30 pounds weight. One ripper is considered more than equivalent in power to three wedges: these last are chiefly used for cleaving small blocks of 2 or 3 feet. The holes are bored about 1 foot apart, so that a large rock requires a great number of rippers, which are struck alternately, and slide down without any great friction between the feathers, and cause a pressure sufficient to cleave down 20 or 25 feet in depth. For deep cuts of 24 feet or even less, it is most usual to drive down the rippers in the evening until the iron begins to feel warm, and leave them for the night; in the ensuing morning a fine hair-line fracture will be found, which is easily increased; whereas should it have been attempted to drive the rippers at once, the iron would be destroyed before the rock would be split.

On the other side of the Channel, wedges only were observed to be in use: perhaps this may account for the small size of the granite blocks used in the construction of the docks at Brest. Powder has been sometimes used near Penryn, particularly in capping, and 1 or $1 \frac{1}{2}$ pound of it has been known in a 9-feet hole to have effected a true fracture 18 feet long by 9 feet wide.

It would be advantageous to the cleavers, or under-contractors for the supply of granite, if engineers, architects and 
building contractors would pay some attention to the cleaving of granite.

Various points could be arranged in the courses of stone for building, particularly in heavy work, which would prevent the present waste of stone and labour. Under the present system, of ordering blocks, it often happens a fine rock is split up irito small blocks; then comes an order for a large block to be delivered instantly for the same building, when small rocks are obliged to be removed and wasted to obtain another fine rock. A little consideration and arrangement would enable the cleaver to split up his large and small rocks to greater advantage. The waste of granite, from the quantity in sight, may be immaterial, but the waste of labour has often occasioned a heavy loss to the cleaver. To convert rocks to the greatest advantage, a considerable number of blocks, with as much variation in their sizes as is suitable to building, should be ordered of each cleaver; and if possible, an allowance should be granted of 3 or 4 inches in the position of the upright joints, so that an error of cleaving a block 1 inch too short might be rectified by procuring the next 1 inch larger.

The beating off roaste, that is, reducing the block with a pick of 20 pounds weight to the exact size required, is the most expensive part of the work; and the cleaver often attempts to cleave too nice, and the block is wasted. Should a good arrangement ever take place in ordering granite, a skill would soon be exerted in the conversion of masses of granite similar to that of a shipbuilder in the conversion of timber.

Blocks under 2 tons are carried on the axletree of a pair of wheels, which are loaded in a manner exactly similar to that proposed by Sir H. Stewart for the removal of large trees. Blocks of a larger size require four wheels, and a greater price, to meet the increased difficulty of loading and carriage. This price is regulated by the cubic foot of finished stone, and the contractor is obliged to deliver at Penryn a block 1 inch larger each way as an allowance for fine cutting; this extra inch is not paid for, and the shipowner complains that granite is the heaviest cargo, since the ton or 14 cubic feet of granite seldom weighs less than $22 \mathrm{cwt}$.

These statements have been made with a hope of attracting attention and inquiry to tracts which seem to have some interest both in a geological and œconomical point of view. Attached is a map and description by R. W. Fox, Esq. of the hard and compact granite.

Enys, Dec. 1832.

John S. ENYS. 